\title{
Nitrogen Use Efficiency and Grain Yield in a Diallelic Cross of Maize Populations
}

\author{
Bello O. B ${ }^{1, *}$, Afolabi M. $S^{2}$, Ige S. A $A^{3}$, Abdulmaliq S. $Y^{4}$, Azeez M. $A^{5}$, Mahmud $J^{6}$ \\ ${ }^{1}$ Department of Biological Sciences, Fountain University, Osogbo, Osun State, Nigeria \\ ${ }^{2}$ Department of Crop Science, Landmark University, Omuaran, Kwara State, Nigeria \\ ${ }^{3}$ Department of Agronomy, University of Ilorin, Ilorin, Nigeria \\ ${ }^{4}$ Department of Agronomy, Ibrahim Badamasi Babangida University, Lapai, Niger State, Nigeria \\ ${ }^{5}$ Department of Pure and Applied Biology, Ladoke Akintola University of Technology, Ogbomoso, Nigeria \\ ${ }^{6}$ Lower Niger River Basin Development Authority, Ilorin, Kwara State, Nigeria
}

\begin{abstract}
The high cost of inorganic fertilizer in West and Central Africa has necessitated an investigation into the nitrogen optimum fertilizer rate for profitable maize production. The performance of ten early open pollinated varieties (OPVs) and their $\mathrm{F}_{1}$ hybrids for grain yield and nitrogen use efficiency (NUE) was assessed, and productive cultivars under low $\mathrm{N}$ fertilizer regimes were also quantified. The trials (ten OPVs and their $\mathrm{F}_{1}$ hybrids) were set up in a split plot arrangement with three $\mathrm{N}$ fertilizer levels $\left(0,45\right.$ and $\left.90 \mathrm{~kg} \mathrm{~N} \mathrm{ha}^{-1}\right)$ as main plot and the genotypes as sub-plot. Each plot was four-row, laid out in a randomized complete block design (RCBD) of four replications. Field experiments were conducted at the teaching Research ( $T$ and R) farm of the University of Ilorin, in the southern Guinea savanna of Nigeria. Planting was carried out during the growing season on $20^{\text {th }} \mathrm{July}, 2005$ and $2^{\text {nd }} \mathrm{July}, 2006$. Ten open pollinated maize cultivars were crossed in a half diallel to generate $45 \mathrm{~F}_{1}$ hybrids during 2004 and 2005 growing seasons. Observed agronomic characteristics were grain yield, establishment plant count, days to $50 \%$ tasselling and silking as well as plant and ear heights. All observed characteristics amongst all the genotypes during growing season in 2005 were better than those in 2006. Expressions of all characteristics in the selected hybrids including the grain yield were relatively higher than the OPVs. The total increase in grain yield was 1.72 $\mathrm{t}$ ha- ${ }^{1}$ and $1.95 \mathrm{t} \mathrm{ha}^{-1}$ for OPVs and hybrids respectively on application of $90 \mathrm{~kg} \mathrm{~N} \mathrm{ha}{ }^{-1}$ over no N-application. However, nitrogen use efficiency (NUE) was optimum at $45 \mathrm{~kg} \mathrm{~N} \mathrm{ha}^{-1}$ in both groups. Grain yield and NUE correlated positively with growth characters measured except for days to $50 \%$ silking. Higher genetic gains were recorded for plant and ear heights. The hybrids Acr 90 Pool 16-Dt $\times$ Ak 95 Dmr-Esrw, Tze Comp4 C2 × Ak 95 Dmr-Esrw and Tze Comp 4 C2 × Tze Comp 3 C2 had higher grain yield with superiority for NUE $(\mathrm{P}<0.05)$. It suggested that the hybrid combinations can further be tested under commercial growing conditions or can be introgressed with other released cultivars to develop low N-tolerant varieties in the in the Nigeria's savanna ecologies.
\end{abstract}

Keywords Nitrogen use efficiency, diallel crosses, maize cultivars, open pollinated varieties

\section{Introduction}

Maize (Zea mays L.) is an important staple food crops and provides bulk of raw materials for the livestock and many agro-allied industries in the world[1,2]. Maize has a wide range of uses than any other cereals because of its world-wide distribution, high yielding nature, ease of processing, readily digestible and relatively lower price of the grain. In recent times, importance of maize production has been widely publicized among farmers of Nigeria. The Nigerian savanna soils however, are fragile, primarily of kaolinitic Alfisols with low organic matter, effective cation

* Corresponding author:

obbello2002@yahoo.com (Bello, O. B)

Published online at http://journal.sapub.org/plant

Copyright (C) 2012 Scientific \& Academic Publishing. All Rights Reserved exchange capacity (ECEC) and plant nutrients[3] creates low yield problems in this agro-climate condition. The attendant problems of the soils frequently deficient in nitrogen $(\mathrm{N})$ due to high rate of leaching, denitrification, decomposition of organic matter and erosive action of rainfall had not only made nitrogen the most limiting nutrient to maize production in Nigeria[3,4] but also enhanced low soil moisture retention. Despite the soil being low in plant available nutrients, $\mathrm{N}$ deficiency is further exacerbated from its continual depletion from the soil pool by removal of $\mathrm{N}$-containing crop residues from the farm. Nitrogen depletion in maize-based systems in some farmers' fields in West African savannah is estimated to be $36-80 \mathrm{~kg} \mathrm{~N} \mathrm{ha}^{-1}$ per year[5]. The resource poor farmers lack cash or access to credit. In view of the fact that farmers hardly adopt option that could provide supplemental $\mathrm{N}$ to maize crops (perhaps manuring, mulching, crop rotation and fallowing schemes), the outcome is that maize production by 
smallholder farmers is normally at a lower capacity (with decrease in the total maize yield) and at a subsistence level solely to meet family consumption. Despite fertilizers recommendations (60 to $120 \mathrm{~kg} \mathrm{~N} \mathrm{ha}{ }^{-1}$ ) for resource poor farmers in the West Africa moist savannah[2,3], less than 20 $\mathrm{kg} \mathrm{N} \mathrm{ha}^{-1}$ used in Nigeria was considered grossly inadequate and $50 \mathrm{~kg}$ nutrient $\mathrm{ha}^{-1}$ fertilizer use was recommended across sub-Saharan Africa by African Heads of States at the Fertilizer Summit held in 2006 at Abuja, Nigeria. Therefore, research is required to increase judicious use of fertilizer and develop sustainable management practices in response to continually increasing economic and environmental pressures[2,6].

The southern Guinea savannah (SGS) of Nigeria has great potential for the expansion of maize production beyond the present level due to its bimodal rainfall pattern, high solar radiation and favourable temperature during the growing season. However, the zone is mitigated with problems such as erratic nature of rainfall pattern, low soil nutrient status and water holding capacity due to fragility of the soil that consistently prone to drought[7-9]. Hybrid maize is well known in the region for its high demand for plant nutrients and other production inputs. The farmers have been indoctrinated with the belief that required amount of inorganic fertilizers need to be applied for maximum performance of hybrid maize and good economic returns. This extra production cost discourages most farmers engaging in hybrid maize production in the country[10]. However, as a result of increasing cost of $\mathrm{N}$ fertilizer due to reduction in government subsidy, poor infrastructure for production and distribution, resulted to inadequate or untimely supply of fertilizers to farmers. Lack of cash or access to credit and perception of cost-benefit ratio also made $\mathrm{N}$ fertilizers sometimes unavailable or are too expensive and often beyond the reach of resource poor farmers who constitute the bulk of maize growers in the moist savannah of West Africa[9]. Maize cultivars that are productive under conditions of low $\mathrm{N}$ availability are therefore highly desirable.

In the development of improved maize productivity in a sustainable fashion in areas with low $\mathrm{N}$ fertility, two basic approaches can be taken. The first, approach is to develop innovative agronomic practices that efficiently utilized $\mathrm{N}$ from organic matter and $\mathrm{N}$ inputs from biological fixation and atmospheric deposition. The second approach is to work with population with the reservoir of genes for low $\mathrm{N}$ tolerance[11]. One strategy for improving the productivity of maize under sub-optimal $\mathrm{N}$ fertility is to use the second approach. The low $\mathrm{N}$ tolerance cultivars are superior in the utilization of available $\mathrm{N}$, either due to enhanced $\mathrm{N}$ - uptake capacity or because of more efficient use of absorbed $\mathrm{N}$ for grain production[12-15]. On the other hand, combination with the first approach will lead to high maize yields. Evaluation of open pollination maize varieties (OPVs) and their $\mathrm{F}_{1}$ hybrids in a diallel cross however could provide a worthwhile knowledge on those genotypes that could be used either directly for cultivation or for extraction of inbred lines for low $\mathrm{N}$ tolerant hybrid development. A corollary is that these genotypes can readily fit into environment with erratic rainfall and low water holding capacity, since they are bred for marginal environments of West and Central Africa. Thus, development of early maturing maize cultivars that remain productive under low $\mathrm{N}$ fertilizer farming system, consistent with the farmers' technologies is therefore a prerequisite to improving adoption of new varieties without increasing production cost in this agro-ecology. This may eventually enhance economic returns of the resource-poor farmers with the proviso that the reductions in fertilizer expenditures are greater than the value of any reduction in saleable maize, resulting from reduced $\mathrm{N}$ fertilizer usage. The objectives of this research therefore was to assess the performance of ten early OPVs and their $F_{1}$ hybrids under low $\mathrm{N}$ fertilizer regimes with the view to identify those that could be cultivated either as varieties per se under the farmers' practices or those that could be introgressed with other released cultivars to develop low $\mathrm{N}$-tolerant varieties in the SGS ecology of Nigeria.

Table 1. Selected physical and chemical characteristics of the soil before growing maize in 2005 and 2006

\begin{tabular}{|c|c|c|}
\hline Physical characteristics & $\begin{array}{c}\text { Amount in } \\
2005\end{array}$ & $\begin{array}{c}\text { Amount in } \\
2006\end{array}$ \\
\hline \multirow{6}{*}{$\begin{array}{c}\text { Texture } \\
\text { pH 1:1 (H2O) } \\
\text { Sand \% } \\
\text { Clay \% } \\
\text { Silt \% }\end{array}$} & Loamy & Loamy \\
\hline & sand & sand \\
\hline & 5.4 & 5.30 \\
\hline & 84.1 & 84.0 \\
\hline & 8.02 & 8.01 \\
\hline & 6.42 & 6.40 \\
\hline \multicolumn{3}{|l|}{ Chemical characteristics } \\
\hline Exchangeable $\mathrm{Ca}^{2+}(\mathrm{Cmol} \mathrm{kg} \mathrm{-1)}$ & 1.12 & 1.10 \\
\hline Exchangeable $\mathrm{Mg}^{2+}(\mathrm{Cmol} \mathrm{kg} \mathrm{-1)}$ & 1.62 & 1.61 \\
\hline Exchangeable $\mathrm{Na}^{+}(\mathrm{Cmol} \mathrm{kg} \mathrm{-1)}$ & 0.19 & 0.18 \\
\hline Exchangeable $\mathrm{K}^{+}(\mathrm{Cmol} \mathrm{kg} \mathrm{-1)}$ & 0.01 & 0.01 \\
\hline Total acidity $\mathrm{H}^{+}{ }^{+}(\mathrm{Cmol} \mathrm{kg} \mathrm{-1})$ & 0.05 & 0.04 \\
\hline Cation exchange capacity ( $\mathrm{Cmol} \mathrm{kg}-1)$ & 2.83 & 2.82 \\
\hline Organic Carbon \% & 0.24 & 0.26 \\
\hline Soil organic matter $\%$ & 1.03 & 1.04 \\
\hline Total Nitrogen $\%$ & 0.24 & 0.26 \\
\hline Available Phosphorus (mg kg-1) & 20.31 & 20.30 \\
\hline
\end{tabular}

\section{Materials and Methods}

Field experiments were conducted at the Teaching and Research (T and R) farm of the University of Ilorin (Latitude $8^{0} 29^{\prime} \mathrm{N}$, Longitude $4^{0} 35^{\prime} \mathrm{E}$ and annual rainfall of $945 \mathrm{~mm}$ ) in the southern Guinea savanna of Nigeria. The soil is classified as Typic paleustalf (United State Department of Agriculture, USDA soil taxonomy). Composite soil samples were collected randomly from the trial site at the depth of $0-15 \mathrm{~cm}$ with an auger prior to planting in 2005 and 2006 .The samples were analyzed in the Soil, Water and Material Testing Laboratory of Lower Niger River Basin Development Authority, Ilorin, Nigeria for physico-chemical analysis (Table 1). The collected samples were air-dried and passed through $2 \mathrm{~mm}$ sieve to remove large particles, debris and stones. The sieved samples were analyzed for $\mathrm{pH}$ in 1:1 soil to water ratio using the Coleman $\mathrm{pH}$ meter. Organic carbon was de- 
termined by Walkley and Black procedure[16]. Total Nitrogen was determined by the micro Kjeldahl method[17], while available phosphorus was extracted by Bray's $\mathrm{P}_{1}$ method[18] and read from the atomic absorption spectrometer. Exchangeable $\mathrm{Ca}, \mathrm{Mg}, \mathrm{K}, \mathrm{Na}$ and effective cation exchangeable capacity (ECEC) were analyzed using Atomic Absorption Spectrophotometery[19], while textural analysis was by hydrometer method. However, rainfall distribution data for the year 2005 and 2006 were also collected (Fig. 1). Rainfall distribution data for the year 2005 and 2006 were also collected at the Lower Niger River Basin Development Authority, Ilorin, Nigeria.

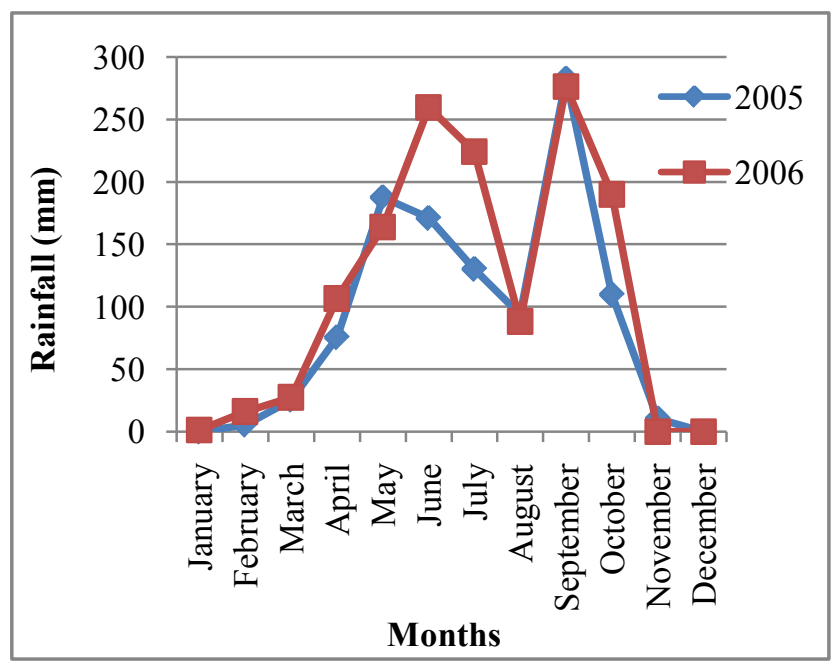

Source: Lower Niger River Basin Development Authority, Ilorin, Nigeria

Figure 1. Monthly rainfall distribution pattern for Ilorin in 2005 and 2006

The genetic materials used were ten open pollinated varieties of maize, selected for grain yield and adaptation to abiotic (drought) and biotic (Stalk rot, Striga and Downy mildew) stress factors. They were early to medium maturing white cultivars with maturity period of 90 to 100 days. The cultivars were obtained from the International Institute of Tropical Agriculture (IITA), Ibadan. The origin, genetic background, breeding emphasis and ecological adaptation of the maize parents are presented in Table 2 . The ten varieties were crossed in a half diallel to generate $45 \mathrm{~F}_{1}$ hybrids during 2004 and 2005 cropping seasons. It is worthwhile to mention that the ultimate goal is not diallel analysis in which using pure lines as parents is necessary. Planting of the ten varieties and their $\mathrm{F}_{1}$ hybrids were carried out during the growing seasons on $20^{\text {th }}$ July, 2005 in the first year and $2^{\text {nd }}$ July, 2006 in the second year. The resultant hybrids were harvested, processed and stored in the cold room prior to field evaluation. The trials were set up in a split plot arrangement with $\mathrm{N}$-level as main plot and the genotypes as sub-plot. Each plot was four-row, laid out in a randomized complete block design (RCBD) of four replications at spacing of $0.75 \mathrm{~m}$ between and $0.50 \mathrm{~m}$ within the rows. Each stand was planted to three seeds but was later thinned to two plants per stand to give a plant population of approximately 53,333 per hectare. Nitrogen fertilizer in form of granular urea was applied at 0 , $45,90 \mathrm{~kg} \mathrm{~N} \mathrm{ha}^{-1}$, while phosphorus and potassium obtained from single super phosphate (SSP) and murate of potash (MOP) were applied at $40 \mathrm{~kg} \mathrm{P}_{2} \mathrm{O}_{5}$ and $60 \mathrm{~kg} \mathrm{~K}_{2} 0 \mathrm{ha}^{-1}$. All the SSP and MOP fertilizers were applied once at planting with $60 \%$ of the rate urea at two weeks after planting (WAP), while the remaining $40 \%$ of urea was applied at six WAP by spot placement. Weed control was undertaken by applying 5 liters per hectare of pre-emergence herbicides $\left(3 \mathrm{~kg} \mathrm{l}^{-1} \mathrm{Me}-\right.$ tolachlor and $170 \mathrm{~g} \mathrm{l}^{-1}$ Atrazine). The field borders were also weeded to minimize encroachment by insects and rodents. The chemical weed control was supplemented by a regime of hand weeding at six WAP. Data were collected from the two middle rows in each plot. Agronomic parameters recorded in each cropping seasons were establishment plant count (EPC), ; plants and ear heights were measured as the distance from the ground level to the flag leaf and the node bearing the uppermost ear, respectively using a measuring tape. Days to $50 \%$ tasselling (TS) and silking (SK) were taken as the date when $50 \%$ of the plants in a plot had tasselled and extruded silk respectively. The anthesis-silking interval was estimated as the difference between days to pollen shed and silking. Moisture at harvest was determined by collection of 500 grain samples from each plot. The samples were first weighed to obtain initial weight, followed by drying to a constant weight in the oven at $80^{\circ} \mathrm{C}$, and the difference between the two weights were recorded as the moisture at harvest. Grain yield was obtained from ear weight per plot (assuming $80 \%$ shelling percentage) and converted to tonnes per hectare after adjusting to $12.5 \%$ moisture content. Nitrogen use efficiency (NUE) was estimated as grain yield per unit of available soil $\mathrm{N}$ as described below.

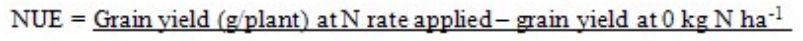
$\mathrm{N}$ applied ( $\mathrm{g} \mathrm{Nf}$ )

Where $\mathrm{g} \mathrm{Nf}=$ Amount of $\mathrm{N}$ applied.

The data were subjected to analysis of variance and pertinent means were separated using Least Significant Difference (LSD) according to[20]. The phenotypic (rph), genotypic ( $\mathrm{rg}$ ) and environmental (re) correlation coefficients were estimated from the mean squares and mean across products as suggested by[21]. PROC GLM model of SAS[22] was used to compute simple linear correlation. Analysis of variance (ANOVA) on individual year basis was first computed before a combined ANOVA across the two years.

\section{Results}

\subsection{Soil Analysis}

Soil samples collected from the trial site before cropping in 2005 and 2006 were analyzed for selected physical and chemical properties (Table 1). The soil texture was loamy sand with similar values of soil properties in both years. The soil had a pH of 5.4 which is moderately acidic. The soil organic matter and total nitrogen content was low, while the soil available phosphate and the exchangeable cations (K, Na, $\mathrm{Ca}$ and $\mathrm{Mg}$ ) were moderate for maize production in this area. 


\subsection{Effect of Cropping Season on Open Pollinated Varieties and their Selected $F_{1}$ Hybrids Performance}

The rainfall in 2006 growing season was more favourable for the expression of all studied characters among the genotypes than 2005 (Fig. 1). Each of the cropping seasons had significant effect on all the characters measured in the open pollinated varieties and hybrids, except for nitrogen use efficiency (NUE) and grain yield in the hybrids (Table 3). The plants were significantly taller, with higher ear placement, subsequently higher grain yield, more efficient utilization of $\mathrm{N}$ and higher anthesis-silking interval. However, expressions of these traits in the hybrids were relatively higher than the OPVs.

\subsection{Effect of $\mathbf{N}$ Fertilizer Rates on Grain Yield, NUE and other Agronomic Characters}

Varying the $\mathrm{N}$-fertilizer rate significantly $(\mathrm{P}<0.05)$ affected the expression of the characteristics measured in both OPVs and hybrids (Table 3). Grain yield increased with the increase in $\mathrm{N}$-dosage in the OPVs and hybrids but was higher in the hybrids relative to OPVs. The NUE of hybrids and OPVs increased significantly $(\mathrm{P}<0.05)$ by increasing the $\mathrm{N}$-level from 0 to $45 \mathrm{~kg} \mathrm{~N} \mathrm{ha}^{-1}$. Though the NUE showed consistent trends in both groups from 45 to $90 \mathrm{~kg} \mathrm{~N} \mathrm{ha}^{-1}$, the increament was significant $(\mathrm{P}<0.05)$ only for hybrids. The grain yield increased significantly $(\mathrm{P}<0.05)$ from 0.89 to $2.18 \mathrm{t} \mathrm{ha}^{-1}$ and 1.35 to $2.68 \mathrm{tha}^{-}{ }^{1}$ for OPVs and hybrids respectively by increasing $\mathrm{N}$-application from 0 to $45 \mathrm{~kg} \mathrm{~N}$ $\mathrm{ha}^{-1}$. The total increase in grain yield observed was $1.72 \mathrm{t}$ ha- ${ }^{1}$ and $1.95 \mathrm{t} \mathrm{ha}^{-1}$ for OPVs and hybrids respectively on application of $90 \mathrm{~kg} \mathrm{ha}^{1}$ over no N-application. Days to $50 \%$ tasselling and silking decreased with increasing $\mathrm{N}$ application rate, while plant and ear heights increased with increasing $\mathrm{N}$ application rate in both groups. Plant and ear heights also differed significantly $(\mathrm{P}<0.05)$ with increase in $\mathrm{N}$-dosage.

\subsection{Interactive Effects of Year $\times$ Nitrogen on Grain Yield and NUE}

The first order interaction of year $\times$ nitrogen was significant for both grain yield and NUE in the OPVs and hybrids (Table 4). Significantly $(\mathrm{P}<0.05)$, higher grain yield was obtained at $90 \mathrm{~kg} \mathrm{~N} \mathrm{ha}^{-1}$ in 2005 than 2006 in both genotypes. Grain yield increased significantly $(\mathrm{P}<0.05)$ at every $\mathrm{N}$ level between 0 and $90 \mathrm{~kg} \mathrm{~N}^{-1}$ with a difference of 1.59 and $1.66 \mathrm{t} \mathrm{ha}^{-1}$ in OPVs and 2.22 and $2.11 \mathrm{t} \mathrm{ha}^{-1}$ in the hybrids at the first and second years respectively. However, NUE was best at $90 \mathrm{~kg} \mathrm{~N} \mathrm{ha}^{-1}$ regardless of the growing season among the genotypes.

Table 2. Origin, genetic background, breeding emphasis and ecological adaptation of the maize parents

\begin{tabular}{|c|c|c|c|c|}
\hline & Genotypes & Origin and genetic background & Breedingemphasis & $\begin{array}{l}\text { Ecological } \\
\text { adaptation }\end{array}$ \\
\hline 1. & $\begin{array}{l}\text { Acr } 90 \text { Pool } \\
16-\mathrm{Dt}\end{array}$ & $\begin{array}{c}\text { Early white dent International Maize and Wheat Improvement Centre } \\
\text { (CIMMYT) cultivar, derived from crosses among large numbers of early late } \\
\text { white flint materials from Mexico, the Caribbean area, Central and South } \\
\text { America. Selected for drought tolerance. }\end{array}$ & $\begin{array}{l}\text { Stalk rot, Striga } \\
\text { and drought tol- } \\
\text { erance. }\end{array}$ & $\begin{array}{l}\text { Forest and } \\
\text { savannah. }\end{array}$ \\
\hline 2. & $\begin{array}{l}\text { Tze Comp } \\
\text { 4-Dmr Srbc2 }\end{array}$ & $\begin{array}{l}\text { Early maturing white and semi dent cultivar, derived from diverse sources of } \\
\text { early mid-altitude germplasm, intermatted with TZESR-W and } \\
\text { DMR-ESRW. }\end{array}$ & $\begin{array}{l}\text { Yield and Striga } \\
\text { tolerance. }\end{array}$ & $\begin{array}{l}\text { Forest and } \\
\text { savannah. }\end{array}$ \\
\hline 3. & Tze Comp4 C2 & $\begin{array}{l}\text { Early maturing white and semi dent cultivar, derived from diverse sources of } \\
\text { early mid-altitude germplasm, intermatted with EV 8430-SR and IK } 8149 \\
\text { SR. It has synchronous male and female flowering, lower plant height and } \\
\text { small tassel size. }\end{array}$ & $\begin{array}{l}\text { Yield and Striga } \\
\text { tolerance. }\end{array}$ & $\begin{array}{l}\text { Forest and } \\
\text { savannah. }\end{array}$ \\
\hline 4. & $\begin{array}{l}\text { Acr } 97 \text { Tze } \\
\text { Comp3 C4 }\end{array}$ & $\begin{array}{l}\text { Early white flint dent cultivar, derived from early mid-altitude germplasm } \\
\text { with EV 8430-SR, DMR-ESRW, TZESR-W and IK } 8149 \text { SR intermatted. }\end{array}$ & $\begin{array}{l}\text { Yield, downy } \\
\text { mildew and Striga } \\
\text { tolerance. }\end{array}$ & $\begin{array}{l}\text { Forest and } \\
\text { savannah. }\end{array}$ \\
\hline 5. & $\begin{array}{l}\text { Hei } 97 \text { Tze } \\
\text { Comp3 C4 }\end{array}$ & $\begin{array}{l}\text { Early white flint dent cultivar, derived from early mid-altitude germplasm } \\
\text { with EV 8430-SR, DMR-ESRW, TZESR-W and IK } 8149 \text { SR intermatted. }\end{array}$ & $\begin{array}{l}\text { Yield, downy } \\
\text { mildew and Striga } \\
\text { tolerance. }\end{array}$ & $\begin{array}{l}\text { Forest and } \\
\text { savannah. }\end{array}$ \\
\hline 6. & $\begin{array}{l}\text { Acr } 94 \text { Tze } \\
\text { Comp5 }\end{array}$ & $\begin{array}{c}\text { Early white flint dent cultivar, derived from early mid-altitude germplasm } \\
\text { with Striga intermatted with TZE-WC3. }\end{array}$ & Striga tolerance. & Savannah. \\
\hline 7. & Tze Comp3 Dt & $\begin{array}{l}\text { Early white flint dent cultivar, derived from diverse sources of early } \\
\text { mid-altitude germplasm with drought tolerant cultivars, intermatted with } \\
\text { TZESR-W and DMR-ESRW. }\end{array}$ & Drought tolerance. & $\begin{array}{l}\text { Forest and } \\
\text { savannah }\end{array}$ \\
\hline 8. & Tze Comp3 C2 & $\begin{array}{l}\text { Early white and flint dent cultivar, derived from diverse sources of early } \\
\text { mid-altitude germplasm, produced by intermating TZESR-W and } \\
\text { DMR-ESRW. }\end{array}$ & $\begin{array}{l}\text { Downy mildew } \\
\text { and Striga toler- } \\
\text { ance. }\end{array}$ & $\begin{array}{l}\text { Forest and } \\
\text { savannah. }\end{array}$ \\
\hline 9. & Ak 95 Dmr-Esrw & $\begin{array}{c}\text { Early maturing and flint dent cultivar, developed from intermating diverse } \\
\text { sources of early mid-altitude germplasm, produced by intermating DMR } \\
\text { sources from Philippines with TZB, TZBP, TZSR and tropical late. Selected } \\
\text { for earliness. }\end{array}$ & $\begin{array}{l}\text { Downy mildew } \\
\text { and Striga toler- } \\
\text { ance. }\end{array}$ & Forest. \\
\hline 10 & Tze Msr-W & $\begin{array}{l}\text { Early white semi dent cultivar, derived from early mid-altitude germplasm, } \\
\text { developed from intermating local and early cultivars with TZSR. }\end{array}$ & $\begin{array}{c}\text { Yield and Striga } \\
\text { tolerance. }\end{array}$ & $\begin{array}{l}\text { Forest and } \\
\text { savannah. }\end{array}$ \\
\hline
\end{tabular}

Source: IITA Archival Report 1988-1992. 
Table 3. Maize grain yield, NUE and agronomic characters in open pollinated maize varieties and their $\mathrm{F}_{1}$ hybrids as affected by $\mathrm{N}$ fertilizer rates in 2005 and 2006 at Ilorin, Nigeria

\begin{tabular}{|c|c|c|c|c|c|c|c|}
\hline Treatments & Grain yield $\left(\mathrm{t} \mathrm{ha}^{-1}\right)$ & NUE & $\begin{array}{l}\text { Establishment plant count } \\
\text { (EPC) }\end{array}$ & $\begin{array}{l}\text { Days to } 50 \% \\
\text { Tasselling (TS) }\end{array}$ & $\begin{array}{l}\text { Days to } 50 \% \\
\text { silking (SK) }\end{array}$ & $\begin{array}{l}\text { Plant } \\
\text { height } \\
(\mathrm{cm})\end{array}$ & $\begin{array}{l}\text { Ear } \\
\text { hight } \\
(\mathrm{cm})\end{array}$ \\
\hline \multicolumn{8}{|c|}{ Open pollinated varieties } \\
\hline Year & & & & & & & \\
\hline 2005 & 2.42 & 1.82 & 39 & 52 & 53 & 129 & 44 \\
\hline 2006 & 2.10 & 1.06 & 35 & 50 & 51 & 113 & 40 \\
\hline LSD $\alpha 0.05$ & $0.08 * *$ & $0.66^{* *}$ & $0.76^{*}$ & $0.75^{* *}$ & $0.85^{*}$ & $3.42 *$ & $2.81 *$ \\
\hline \multicolumn{8}{|l|}{ N Levels ( $\mathrm{kg} \mathrm{N} \mathrm{ha}^{-1}$ ) } \\
\hline 45 & $\begin{array}{l}0.89 \\
2.18\end{array}$ & 1.00 & 36 & 54 & 56 & 101 & 35 \\
\hline 90 & $\begin{array}{l}2.18 \\
2.61\end{array}$ & 2.07 & $\begin{array}{l}38 \\
37\end{array}$ & 52 & 53 & 121 & 37 \\
\hline \multirow{2}{*}{$\operatorname{LSD} \alpha 0.05$} & $0.67 *$ & $0.45 *$ & NS & $\begin{array}{c}51 \\
0.45 *\end{array}$ & $\begin{array}{c}52 \\
0.91 *\end{array}$ & $\begin{array}{c}129 \\
3.54 *\end{array}$ & $2.75 *$ \\
\hline & & & $F_{1}$ Hybrids & & & & \\
\hline Year & & & & & & & \\
\hline 2005 & 3.71 & 2.57 & 37 & 53 & 54 & 129 & 44 \\
\hline 2006 & 3.70 & 2.51 & 33 & 50 & 51 & 118 & 40 \\
\hline $\operatorname{LSD} \alpha 0.05$ & NS & NS & $0.43^{*}$ & $0.36^{*}$ & $0.97^{*}$ & $3.28^{*}$ & $2.81 *$ \\
\hline \multicolumn{8}{|l|}{ N Levels $\left(\mathrm{kg} \mathrm{N} \mathrm{ha}^{-1}\right)$} \\
\hline 0 & 1.35 & 1.0 & 36 & 54 & 56 & 110 & 39 \\
\hline 45 & 2.68 & 2.14 & 37 & 51 & 54 & 122 & 40 \\
\hline 90 & 3.30 & 2.71 & 36 & 50 & 52 & 130 & 41 \\
\hline $\operatorname{LSD} \alpha 0.05$ & $0.98^{*}$ & $0.51 *$ & NS & $0.38^{*}$ & $0.96^{*}$ & $3.11 *$ & $2.61 *$ \\
\hline
\end{tabular}

*, **; Significant $\mathrm{F}$ test at 0.05 and 0.01 levels of probability respectively.

Table 4. Interactive effects of year $\times$ nitrogen for grain yield and NUE in open pollinated varieties and their selected $\mathrm{F}_{1}$ hybrids in 2005 and 2006 at Ilorin, Nigeria

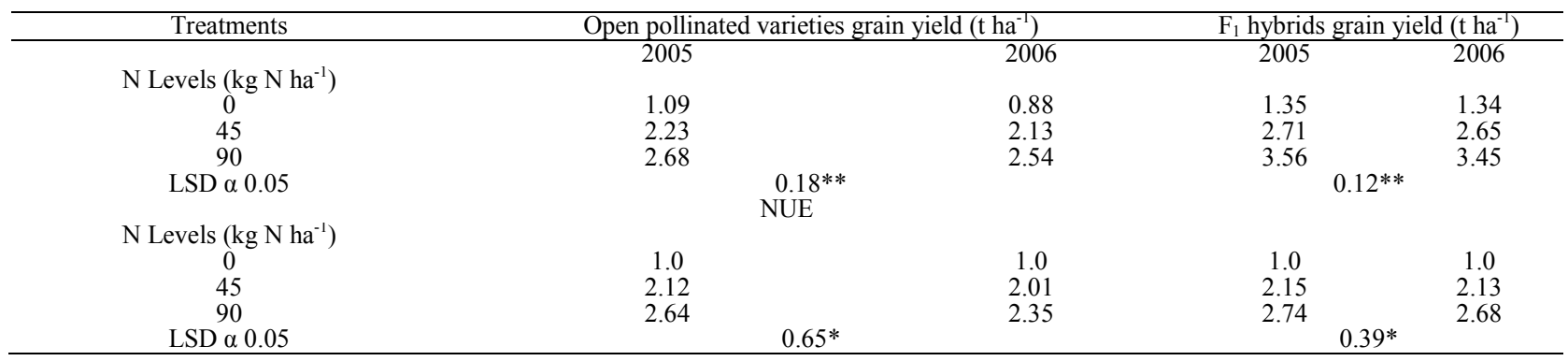

$*$,**; Significant $\mathrm{F}$ test at 0.05 and 0.01 levels of probability, respectively

Table 5. Genotypic means for maize grain yield, NUE and agronomic parameters in 10 open pollinated varieties and their selected $F_{1}$ hybrids in 2005 and 2006 at Ilorin, Nigeria

\begin{tabular}{|c|c|c|c|c|c|c|c|c|}
\hline \multirow[t]{2}{*}{ Genotypes } & Grain yield $\left(\mathrm{t} \mathrm{ha}^{-1}\right)$ & \multirow{2}{*}{ NUE } & \multirow{2}{*}{$\begin{array}{c}\text { Establishment plant } \\
\text { count (EPC) }\end{array}$} & \multicolumn{2}{|c|}{$\begin{array}{c}\text { Days to 50\% } \\
\text { tasselling (TS) }\end{array}$} & \multicolumn{2}{|c|}{$\begin{array}{c}\text { Days to } 50 \% \text { silking } \\
\text { (SK) }\end{array}$} & \multirow{2}{*}{$\begin{array}{c}\text { Plant } \\
\text { Height }(\mathrm{cm}) \\
\end{array}$} \\
\hline & \multicolumn{5}{|c|}{ Open pollinated varieties } & & & \\
\hline & Acr 90 Pool 16-Dt & 2.33 & 2.34 & 35 & 51 & 53 & 124 & 44 \\
\hline & Гze Comp 4-Dmr Srbc2 & 2.29 & 1.16 & 38 & 50 & 54 & 122 & 35 \\
\hline & Tze Comp4 C2 & 2.24 & 1.53 & 34 & 51 & 53 & 114 & 41 \\
\hline & Acr 97 Tze Comp3 C4 & 2.21 & 1.24 & 37 & 51 & 54 & 114 & 42 \\
\hline & Hei 97 Tze Comp3 C4 & 2.18 & 1.34 & 39 & 50 & 53 & 114 & 39 \\
\hline & Acr 94 Tze Comp5 & 2.24 & 1.33 & 37 & 51 & 54 & 118 & 38 \\
\hline & Tze Comp3 Dt & 2.38 & 2.28 & 40 & 49 & 53 & 135 & 53 \\
\hline & Tze Comp3 C2 & 2.22 & 1.34 & 37 & 51 & 53 & 117 & 42 \\
\hline & Ak 95 Dmr-Esrw & 2.27 & 1.56 & 36 & 51 & 54 & 122 & 44 \\
\hline & Tze Msr-W & 2,24 & 1.13 & 39 & 50 & 54 & 128 & 41 \\
\hline & $\operatorname{LSD} \alpha 005$ & $0.14 *$ & $0.34 *$ & $0.45 *$ & $0.87 *$ & $0.56 *$ & $6.04 * *$ & $4.42 * *$ \\
\hline \multicolumn{9}{|c|}{$\mathrm{F}_{1}$ hybrids } \\
\hline Acr 94 & Tze Comp 5 x Tze Comp4 C2 & 3.46 & 1.90 & 35 & 50 & 52 & 137 & 45 \\
\hline Acr 90 & Pool 16-Dt x Tze Comp3 C2 & 3.48 & 1.46 & 38 & 50 & 53 & 129 & 51 \\
\hline Acr $97 \mathrm{~T}$ & ze Comp3 C4 x Tze Comp3 Dt & 3.34 & 1.28 & 34 & 51 & 54 & 128 & 52 \\
\hline Acr $90 \mathrm{I}$ & Pool 16-Dt x Ak 95 Dmr-Esrw & 3.48 & 1,98 & 37 & 49 & 53 & 137 & 49 \\
\hline Tze C & omp3 Dt x Ak 95 Dmr-Esrw & 3.43 & 1.51 & 39 & 50 & 53 & 129 & 44 \\
\hline Tze Comp & 4-Dmr Srbc2 x Ak 95 Dmr-Esrw & 3.38 & 1.36 & 37 & 51 & 54 & 135 & 40 \\
\hline Ak 9 & 5 Dmr-Esrw x Tze Msr-W & 3.44 & 1.81 & 40 & 49 & 53 & 128 & 43 \\
\hline Tze $C$ & Comp3 Dt x Tze Comp3 C2 & 3.36 & 1.56 & 37 & 50 & 54 & 134 & 50 \\
\hline Acr 94 & Tze Comp5 x Tze Comp3 Dt & 3.34 & 1.48 & 36 & 50 & 53 & 126 & 53 \\
\hline Acr 90 & Pool 16-Dt x Tze Comp3 Dt & 3.48 & 1.90 & 39 & 49 & 52 & 128 & 52 \\
\hline Acr 9 & 4 Tze Comp5 x Tze Msr-W & $\begin{array}{l}3.40 \\
3.38\end{array}$ & 1.46 & 35 & 50 & 52 & 127 & 49 \\
\hline Tze Con & mp 4-Dmr Srbc2 x Tze Msr-W & 3.43 & 1.58 & 38 & 51 & 53 & 129 & 44 \\
\hline Tze & Comp4 C2 x Tze Comp3 Dt & 3.48 & $\begin{array}{l}1.00 \\
1,98\end{array}$ & 34 & 50 & 52 & 135 & 40 \\
\hline Tze C & Comp4 C2 x Tze Comp3 C2 & 3.43 & 1.98 & 36 & 51 & 54 & 128 & 43 \\
\hline & LSD $\alpha 005$ & $0.17 *$ & $0.56^{*}$ & $0.67 *$ & $0.89 *$ & $0.66^{*}$ & $5.98 * *$ & $4.30 * *$ \\
\hline
\end{tabular}

*,**; Significant $\mathrm{F}$ test at 0.05 and 0.01 levels of probability respectively 
Table 6. Simple linear correlation coefficient of grain yield, NUE and agronomic parameters in 10 open pollinated maize varieties in 2005 and 2006 at Ilorin, Nigeria

\begin{tabular}{ccc}
\hline & Grain yield (t ha-1) & NUE \\
\cline { 2 - 3 } Establishment plant count & $0.320^{* *}$ & $0.315^{* *}$ \\
Days to 50\% tasselling & $0.235^{* *}$ & $0.261^{* *}$ \\
Days to 50\% silking & 0.042 & -0.016 \\
Plant height & $0.147^{* *}$ & $0.140^{* *}$ \\
Ear height & $0.235^{* *}$ & $0.125^{*}$ \\
NUE & $0.521^{* *}$ & \\
\hline
\end{tabular}

*, **; Significant $\mathrm{F}$ test at 0.05 and 0.01 levels of probability respectively

Table 7. Simple linear correlation coefficient of maize grain yield, NUE and agronomic characteristics in selected $F_{1}$ hybrids in 2005 and 2006 at Ilorin, Nigeria

\begin{tabular}{ccc}
\hline & Grain yield (t ha-1) & NUE \\
\hline Establishment plant count & $0.411^{* *}$ & $0.325^{* *}$ \\
Days to 50\% tasselling & $0.387^{* *}$ & $0.341^{* *}$ \\
Days to 50\% silking & 0.009 & -0.076 \\
Plant height & $0.345^{* *}$ & 0.134 \\
Ear height & $0.140^{*}$ & $0.110^{*}$ \\
NUE & $0.242^{* *}$ & \\
\hline
\end{tabular}

*, **; Significant $\mathrm{F}$ test at 0.05 and 0.01 levels of probability respectively

\subsection{Genotypic Performance for Grain Yield, NUE and other Agronomic Characters}

The hybrids differed significantly $(\mathrm{P}<0.05)$ for all the traits and showed superiority with respect to grain yield than their respective OPVs (Table 5). There was no significant genotype $\times \mathrm{N}$ fertilizer effects for grain yield and NUE in this study. Two drought tolerant varieties (Acr 90 Pool 16-Dt and Tze Comp3 Dt) not only had the highest grain yield and NUE among OPVs, but also specifically combined well with each other and some cultivars. While Acr 90 Pool 16-Dt favourable combined with Tze Comp3 Dt, Tze Comp3 C2 and Ak 95 Dmr-Esrw for grain yield, var. Tze Comp3 Dt combined well with Tze Comp4 C2. The genotypes were also taller with higher ear placement, increase in days to $50 \%$ tasselling and silking. Grain yield among the parents showed similar trends with the hybrids. However, correlation of grain with other traits among the parents and hybrids showed that grain yield correlated positively and significantly $(\mathrm{P}<$ 0.05 ) with growth characteristics measured except days to $50 \%$ silking (Table 6 and 7). NUE correlated positively and significantly $(\mathrm{P}<0.05)$ with all agronomic characters except days to $50 \%$ silking in the OPVs. However, association of NUE with plant height and days to $50 \%$ silking was not significant among the hybrids.

\subsection{Genotypic and Phenotypic Variances for Grain Yield and other Agronomic Characteristics}

Estimates of genotypic and phenotypic variances as well as coefficients of genotypic and phenotypic variations, and genetic advance are presented in Table 8 . The value for genotypic variances ranged from 3.2 for grain yield to 608.6 for plant height, while the phenotypic variances ranged from 17.4 for establishment plant count to 1062.5 for plant height. The coefficients of variations also showed that the phenotypic coefficients of variations (PCV) were higher than the genotypic coefficients of variations (GCV) for all the parameters measured. Plant height had the highest GCV (129.6) and PCV (252.9). Similarly, highest genetic gain of $1162.8 \%$ was recorded for plant height and the least genetic gain of $11.9 \%$ for days to $50 \%$ silking.

Table 8. Estimates of genotypic and phenotypic variances, coefficients of genetic variability and genetic advance in agronomic characters among open pollinated maize varieties and their selected $\mathrm{F}_{1}$ hybrids as affected by $\mathrm{N}$ fertilizer rates in 2005 and 2006 at Ilorin, Nigeria

\begin{tabular}{cccccc}
\hline Character & $\delta^{2} \mathrm{~g}$ & $\delta^{2} \mathrm{p}$ & $\mathrm{GCV}$ & $\mathrm{PCV}$ & $\mathrm{GA}(\%)$ \\
\hline Establishment plant & 3.6 & 17.4 & 52.4 & 118.8 & 12.2 \\
count & & & & & \\
Days to 50\% tasselling & 32.7 & 156.3 & 74.1 & 159.8 & 27.0 \\
Days to 50\% silking & 10.5 & 317.2 & 16.8 & 254.6 & 11.9 \\
Plant height & 608.6 & 1062.5 & 129.6 & 517.5 & 1162.8 \\
Ear height & 121.4 & 1054.6 & 128.7 & 213.6 & 175.8 \\
Grain yield & 3.2 & 3.5 & 71.6 & 75.3 & 95.0 \\
\hline
\end{tabular}

$\delta^{2} \mathrm{~g}$, Genotypic variance; $\delta^{2} \mathrm{p}$, phenotypic variance; GCV, genotypic coefficient of variation; $\mathrm{PCV}$, phenotypic coefficient of variation; $\mathrm{GA}$, genetic advance.

\section{Discussion}

The release of improved stress-tolerant maize varieties and hybrids has sparked optimism for increased maize productivity in Nigeria. These cultivars have the potential to provide farmers with opportunities to overcome the challenges to maize production. The cultivation of these cultivars in this agro-ecology could increase maize production and thereby enhance food security. Although rainfall distribution throughout the duration of these studies appeared favourable for crop growth and expression of studied traits in both OPVs and the $\mathrm{F}_{1}$ hybrids, the second year precipitation was more beneficial (Fig. 1). The results from this experiment showed that hybrid maize efficiently utilized nitrogen better than OPVs as per earlier reports in Nigeria[9,10,23]. In both years, hybrids gave higher yield than the OPVs even at low soil N status[24-27]. Consequently, maize yield increased with increasing nitrogen availability and this is in agreement with previous reports by many workers[4,10,15,28-31]. Cultivars identified as less responsive to applied $\mathrm{N}$ sometimes perform better at low $\mathrm{N}$ than do N-responsive hybrids or OPVs[32]. The low $\mathrm{N}$ tolerant cultivars are superior in the utilization of available $\mathrm{N}$, either due to enhanced uptake capacity or because of more efficient use of absorbed $\mathrm{N}$ in grain production[9,12,28,33]. However, number of days recorded in 2006 especially at anthesis was less than that recorded in 2005, which probably facilitated optimum utilization of available soil nutrients within the few days. This probably explains the higher grain yield and superiority in $\mathrm{N}$ utilization observed in the OPVs in 2005 relative to 2006 (Table 3), and also the significant year $\mathrm{x}$ nitrogen interaction for this character in both parents and hybrids (Table 4). Values for NUE, plant and ear heights were higher in 2005 compared to 2006 in both OPVs and hybrids. This observation tends to underscore the importance of moisture availability especially at anthesis in the accumulation of photo assimilates as well as 
its translocation for grain production in maize. Grain yield and NUE increased in a consistent manner with increasing $\mathrm{N}$ rate in both parents and hybrids (Table 3 ). This is in line with previous reports $[9,14,24,26,28,34]$ that variation in $\mathrm{N}$ supply affects both growth and development of maize plants. The capacity to utilize $\mathrm{N}$ as measured by NUE and consequently grain yield in this study was optimum at $45 \mathrm{~kg} \mathrm{~N} \mathrm{~h}^{-1}$ in both varieties and hybrids which were similar to the result obtained by[35] in the northern Guinea savannah of Nigeria in which the author reported a yield increase of $200 \%$ over the control at $40 \mathrm{~kg} \mathrm{~N}$ ha-1 in two maize varieties of different maturity periods. This result is also in support by earlier findings $[4,12,31,36]$ on increase in grain yield and NUE at low N levels. Reference[10] similarly observed that maize varieties responded adequately well to nitrogen application in the southern Guinea savanna of Nigeria and gave over $3 \mathrm{t}$ ha-1 grain yield by applying as low as $50 \mathrm{~kg} \mathrm{~N}$ ha-1. The authors suggested that this could erase producer fears that without high $\mathrm{N}$ input, hybrid maize would not give some appreciable returns. However, there was no significant genotype $\times \mathrm{N}$ fertilizer effects for grain yield and NUE in this study similar to the findings of earlier workers[37,38], but contradicts- the findings of [39] who observed that maize differed in their capacity for $\mathrm{N}$ uptake, assimilation and redistribution of $\mathrm{N}$ from vegetative to reproductive tissues. The fact that the OPVs used in this study are of the same maturing group may be responsible for the difference in the two results.

High phenotypic coefficients of variations values observed in both OPVs and hybrids may indicate significant year $\times$ nitrogen interactions for all the characters measured (Table 8). This therefore affirmed that the populations used in this study showed a wide range of genetic variability under different $\mathrm{N}$ fertilizer rates. Genetic differences have been observed among maize genotypes (inbred lines, hybrids and OPVs) in response to $\mathrm{N}$ fertilizer application and efficient utilization of absorbed $\mathrm{N}$ for grain yield[12,13,40-43]. The high genetic gain of plant and ear heights signify broader genetic base for the two characteristics and could be selected for genetic improvement of maize under different $\mathrm{N}$ regimes, as earlier suggested[38,44]. Though low genetic gain was recorded for days to $50 \%$ silking and days for establishment count, there is a significant variability in these traits and hence may also be useful in maize breeding programme. Grain yield correlated positively with most of the parameters measured and this has also been reported by previous researchers $[45,46]$.

\section{Conclusions}

Two drought tolerant varieties (Acr 90 Pool 16-Dt and Tze Comp3 Dt) that combined well with specific cultivars for grain yield and NUE probably have gene pools for low $\mathrm{N}$ tolerance. Therefore, these varieties can further be tried under farmers' growing conditions or could be hybridized for development of inbred lines in the development of $\mathrm{N}$ stress-tolerance varieties for cultivation in the southern Guinea savanna ecology.

\section{ACKNOWLEDGEMENT}

Mr. Olujide, Bankole Bodunde of the Soil, Water and Material Testing Laboratory, Lower Niger River Basin Development Authority, Ilorin, Nigeria is highly appreciated for the soil analysis.

\section{REFERENCES}

[1] Bello OB, Abdulmaliq SY, Afolabi MS and Ige SA (2010). Correlation and path coefficient analysis of yield and agronomic characters among open pollinated maize varieties and their $F_{1}$ hybrids in a diallel cross. Afr. J. Biotech., 9(18); 2633-2639

[2] Undie UL, Uwah DF and Attoe EE (2012). Growth and development of late season maize/soybean intercropping in response to nitrogen and crop arrangement in the forest agro-ecology of South Southern Nigeria. Int. J. Agric. Res., 7 (1): $1-16$.

[3] Carsky RJ and Iwuafor ENO (1999). Contribution of soil fertility research and maintenance to improved maize production and productivity in sub-Saharan Africa. In. B. Badu-Apraku et al., (eds).Strategy for sustainable maize production in West and Central Africa. Proc. Regional Maize Workshop, IITA-Cotonou, Benin Republic. 21-25 Apr. 1997. West and Central Africa Collaborative Maize Research Network, International Institute of Tropical Agriculture, Ibadan, Nigeria.

[4] Adekayode FO and Ogunkoya MO (2010). Effect of quantity and placement distances of inorganic 15-15-15 fertilizer in improving soil fertility status and the performance and yield of maize in a tropical rain forest zone of Nigeria. J. Soil Sci. Environ. Managem., 1(7); 155-163.

[5] Sanginga N, Okogun JA, Vanlauwe B, Diels J, Carsky RJ and Dashiell K (2001). Nitrogen contribution of promiscuous soybeans in maize based cropping systems. SSSA Special Publication 58, Madison, USA, pp. 157-177.

[6] Yusuf AA, Iwuafor ENO, Abaidoo RC, Olufajo OO and Sanginga N (2009). Effect of crop rotation and nitrogen fertilization on yield and nitrogen efficiency in maize in the northern Guinea savanna of Nigeria, Afr. J. Agric. Res., 4(10): 913-921.

[7] Fakorede MAB, Badu-Apraku B, Coulibaly O and Fajemisin JM (2001). Impact challenges and prospect of maize research and development in west and central Africa. Proceedings of a regional maize workshop, 4-7 May, 1999, WECAMAN/IITA Cotonou, Benin Republic, pp 45.

[8] Bello OB (2008). Combining ability for maize grain yield in striga endemic and non-endemic environments of the southern Guinea savanna, Nigeria. Ph.D. Thesis. The University of Ilorin, Ilorin, Nigeria, pp 86.

[9] Onasanya RO, Aiyelari OP, Onasanya A, Oikeh S, Nwilene FE and Oyelakin OO (2009). Growth and yield response of 
maize (Zea mays L) to different rates of nitrogen and phosphorus fertilizers in southern Nigeria. World J. Agric. Sci., 5(4): 400-407.

[10] Kogbe JOS and Adediran JA (2003). Influence of nitrogen, phosphorus and potassium application on the yield of maize in the savanna zone of Nigeria. Afri. J. Biotech., 2(10): 345-349.

[11] Smith ME, Miles CA and Beem J V (1994). Genetic improvement of maize for nitrogen use efficiency in eastern and southern Africa. In: Jewell DC., Waddington SH, Ranson JK, Pixley KV (eds). Maize research for stress environment. Proceedings of the fourth Eastern and Southern Africa Regional Maize Conference, 28-31 April, 1994, Harare, Zimbabwe, pp. 39-43.

[12] Lafitte HR and Edmeades GO (1994). Improvements of tolerance to low soil nitrogen in tropical maize. I Selection criteria. FieldCrops Res., 39: 1-14.

[13] Wajid A, Ghaffar A, Maqsood M, Hussain K and Nasim W (2007). Yield response of maize hybrids to varying nitrogen rates. Pak. J. Agri. Sci., 44(2): 217-220.

[14] Hokmalipour S, Shiri-e-Janagard M, Darbandi MH, Peyghami-e-Ashenaee F, Hasanzadeh M, Seiedi MN and Shabani R (2010) Comparison of agronomical nitrogen use efficiency in three cultivars of corn as affected by nitrogen fertilizer levels. World Appl. Sci. J., 8(10): 1168-1174.

[15] Ayeni LS (2011). Integrated plant nutrition management: A panacea for sustainable crop production in Nigeria. Int. J. Soil Sci., 6 (1): 19-24.

[16] Nelson DW and Somers LE (1992). Total carbon, total organic carbon and organic matter. In: Miller et al., (ed). Methods of soil analysis, Part 2, $2^{\text {nd }}$ ed., Agronomy Monograph, 27, ASA, Madison, WI, pp. 539-580.

[17] Bremner JM (1965). Total nitrogen. I methods of soil analysis. II chemical and microbiological properties. In: Black CA, Evans DD., White JL, Ensminger LE, Clerk FE and Dinauer RC (eds). Agronomy Monograph, 9, American Society of Agronomy Madison, Wisconsin, USA, pp. 26.

[18] Bray RH and Kurtz LT (1945). Determination of total organic and available forms of phosphorus in soils. Soil Sci., 59: $39-45$.

[19] International Institute of Tropical Agriculture (1989). Automated and semi-automated methods for soil and plant analysis Manual series No. 7, IITA, Ibadan, Nigeria, pp. 726.

[20] Gomez AG and Gomez AA (1984). Statistical procedures for Agricultural research. International Rice Research Institute Book, $2^{\text {nd }}$ ed., John Wiley and Sons Inc. NY.

[21] Mode CJ and Robinson HF (1959). Pleiotropism and the genetic variance and covariance. Biometrics 15: 518-537.

[22] SAS Institute, (2007). SAS system for windows version 9.2. SAS Institute. Cary, NC.

[23] Akintoye HA, Kling JG, and Lucas EO (1999). N use efficiency of single, double and synthetic maize lines grown at 4 $\mathrm{N}$ levels in three ecological zones of West Africa. Field Crops Res., 60, pp. 189-199.

[24] Manal HM and Aly AA (2008). Yielding ability and nitrogen use efficiency in maize inbred lines and their crosses. Int. J.
Agric. Res., 3: 27-39.

[25] Waseem M, Zamir SI, Ali A and Iqbal A (2007). Influence of nitrogen sources on quantitative and qualitative traits of maize. Pak. J. Life Soc. Sci., 5(1-2): 11-14.

[26] Arif M, Jan MT, Khan NU, Akbar H, Khan SA, Khan MJ, Khan A, Iqbal MI, Saeed M and Iqbal A (2010). Impact of plant populations and nitrogen levels on maize. Pak. J. Bot., 42(6): 3907-3913.

[27] Waseem M, Ali A, Tahir M and Hussain M (2011). Ramifications of different externally applied nitrogen sources on the physiology and yield of hybrid maize (Zea mays L.). Afr. J. Agric. Res., 6(22): 5156-5167.

[28] Hanan S, Siam G, Abd-El- Kader M and El-Alia HI (2008). Yield and yield components of maize as affected by different sources and application rates of nitrogen fertilizer. Res. J. Agric. Biol. Sci., 4(5): 399-412.

[29] Pablo BA, Echeverría EH, Rozas RHS and Andrade HF (2008). Nitrogen use efficiency in maize as affected by nitrogen availability and row spacing. Agron. J., 100: 1094-1100.

[30] Helong Y, Guifen C and Dayou L (2009). Research and application of precision fertilization on maize. International Federation Information Processing Book Series. 293: 477-486.

[31] Gagnon B and Ziadi N (2010). Grain corn and soil nitrogen responses to side-dress nitrogen sources and applications. Agron. J., 102: 1014-1022.

[32] Singh D (2010). Impact of scheduling nitrogen on productivity of single cross maize (Zea mays L.) hybrids. Indian J. Agric. Sci., 80 (7): 649-651.

[33] Matthew DR (2011).Nitrogen rate and timing considerations for sweet corn. Proceedings of the 2011 Wisconsin Crop Management Conference, 50: 123-130.

[34] McCullough DE, Girardin P, Mihajlovic M, Aguilera A and Tollenaar M (1994). Influence of N supply on development and dry matter accumulation of an old and new maize hybrid. Can. J. Plant Sci., 74: 471-477.

[35] Elemo KA (1997). Extra-early and early maize varieties as affected by rate and time of nitrogen fertilization. In: Contribution of food self-sufficiency: Maize research and development in West and Central Africa. Proceedings of a regional maize workshop, IITA, Cotonou, Benin Republic, pp. 241-246.

[36] Namakka AI, Abubakar U, Sadik AI, Sharifai AI and Hassas AH (2008). Effect of sowing date and nitrogen level on yield and yield components of two extra early maize varieties (Zea mays L.) in Sudan savanna of Nigeria. ARPN J. Agric. Biol. Sci., 3(2): 46-51.

[37] Ma BL, Lianne MD and Edward GG (1999). Soil nitrogen amendment effects on nitrogen uptake and grain yield of maize. Agron J. 91: 650-656.

[38] Tittonell P, Vanlauwe B, Corbeels M and Giller KE (2008) Yield gaps, nutrient use efficiencies and response to fertilizers by maizeacross heterogeneous smallholder farms of western Kenya. Plant Soil, 313: 19-37.

[39] Bertin P and Gallais A (2000). Physiological and genetic 
basis of nitrogen use efficiency in maize. I. Agrophysiological results. Maydica, 45: 53-66.

[40] Banziger M, Lafitte HR, Edemeades GO, Betran FJ, Berk DL and Elings A (1999). Recent advances in breeding for tolerance to low nitrogen in tropical maize, pp. 21-34. In. Badu-Apraku B, Fakorede MAB, Ouedraogo M and Quin FM (eds). Proceedings of a regional maize workshop, 21-25 April, 1997, IITA Cotonou, Benin Republic.

[41] Kling JG, Heuberger HT, Oikeh SO, Akintoye HA and Horst WJ (1997). Potential for developing nitrogen-use efficient maize for low-input Agricultural systems in the moist savannas of Africa. In: Edemeades GO, Banziger M, Mickelson HR, Pena-valdiva CB (eds). Developing drought and low-N tolerant maize. Proceedings of a symposium. March, 25-29, 1996, CIMMYT, El. Batan, Mexico, Mexico DF, pp. 490-501.

[42] Abdel-Rahman AM, Magboul EL and Abdelatief EN (2002). Effects of sowing date and cultivar on the yield and yield components of maize in northern Sudan.. In: Friesen DK and
Palmer AFE (ed.) Integrated approaches to higher maize productivity in the new millennium: Proceedings of the $7^{\text {th }}$ Eastern and Southern Africa Regional Maize Conference, Nairobi, Kenya. 5-11 Feb, 2001. CIMMYT and Kenya Agriculture Research. Institute, Nairobi, pp. 295-298.

[43] Khaliq T, Ahmad A, Hussain A, Ranjha AM and Ali MA (2008). Impact of nitrogen rates on growth, yield and radiation use efficiency of maize under varying environments. Pak. J. Agri. Sci., 45(3): 1-7.

[44] Yusuf M (2010). Genetic variability and correlation in single cross hybrids of quality protein maize (Zea Mays L.). Afri. J. Food Agric. Nutrit. Developm., 10(2): 2166-2175.

[45] Tenaw W (2000). Effect of nitrogen fertilizer rates and plant density on grain yield of maize. Afr. Crop Sci. J., 8(3): 273-282.

[46] Hefny MM (2007). Estimation of quantitative genetic parameters for nitrogen use efficiency in Maize under two nitrogen rates. Int. J. Plant Breed. Genet., 1: 54-66. 